\title{
Effect of various salt concentrations on the ruminal parameters of goats
}

\author{
E.C.B. Costa1, G.G.L. Araújo², J.S. Oliveira1', E.M. Santos', A.F. Perazzo으, G.A. Pereira1, F.N.S. \\ Santos $^{1 \#}$ \& A.M. Zanine ${ }^{3}$ \\ 1Department of Animal Science, Federal University of Paraíba, PB, 58397-000, Areia, Brazil \\ 2Brazilian Enterprise for Agricultural Research, Pernambuco, PE, 56302-970, Petrolina, Brazil \\ 3Department of Animal Science, Federal University of Maranhão, MA, 65500-000, Maranhão, Brazil
}

(Submitted 22 April 2020; Accepted 10 July 2020; Published 3 October 2020)

\begin{abstract}
Copyright resides with the authors in terms of the Creative Commons Attribution 4.0 South African Licence.
See: http://creativecommons.org/licenses/by/4.0/za

Condition of use: The user may copy, distribute, transmit and adapt the work, but must recognise the authors and the South African Journal of Animal Science.
\end{abstract}

\begin{abstract}
The objective of this study was to evaluate the effects of various concentrations of sodium chloride $(\mathrm{NaCl})$, magnesium chloride $\left(\mathrm{MgCl}_{2}\right)$, and calcium chloride $\left(\mathrm{CaCl}_{2}\right)$ on the growth and in vitro fermentation of cellulolytic, glycolytic, and amylolytic microorganisms from the rumen of a goat. Six concentrations of each salt were tested separately, namely $0 \mathrm{mg} / \mathrm{dL}, 100 \mathrm{mg} / \mathrm{dL}, 200 \mathrm{mg} / \mathrm{dL}, 400 \mathrm{mg} / \mathrm{dL}, 800 \mathrm{mg} / \mathrm{dL}$, and 1600 $\mathrm{mg} / \mathrm{dL}$ in the culture medium. The experiments were conducted in a completely randomized design, in a $6 \mathrm{x}$ 3 factorial arrangement of salt concentration and substrate (starch, cellulose, and glucose) with three replications of each treatment combination. Concentrations of microbial protein, ammonia $\left(\mathrm{NH}_{3}-\mathrm{N}\right)$, and volatile fatty acids (acetate, propionate, and butyrate) were measured. A quadratic effect of $\mathrm{CaCl}_{2}$ concentration on the production of microbial protein was observed in the cellulose medium. The effect of $\mathrm{MgCl}_{2}$ on $\mathrm{NH}_{3}-\mathrm{N}$ production in the cellulose medium decreased linearly. Propionate concentration decreased linearly with increasing levels of $\mathrm{NaCl}$ and $\mathrm{MgCl}_{2}$ in the media containing starch. There was a decreasing linear effect of $\mathrm{MgCl}_{2}$ on the concentration of butyrate in the media containing glucose. In conclusion, concentrations of $\mathrm{NaCl}$ and $\mathrm{CaCl}_{2}$ up to $1,600 \mathrm{mg} / \mathrm{dL}$ did not affect the microbial activity of starch, cellulose, and glucose-fermenting organisms. However, the microbial activity of starch-fermenting microbes was inhibited at salt concentrations above $800 \mathrm{mg} / \mathrm{dL}$. Thus, brackish water could be used by goats in semiarid regions, but its use should be managed carefully so that it does not have a negative impact on rumen microbial populations.
\end{abstract}

Keywords: cellulose, glucose, saline water, starch, ruminants

\#Corresponding author: nayssonzootecnista@gmail.com

\section{Introduction}

The supply of water has continually become increasingly scarce, especially in arid and semi-arid regions (Araújo et al., 2010). Brackish water represents a risk to health for animals and people. However, it is necessary to identify the tolerance of ruminants to minerals in water in some animal production systems in regions with seasonal rainfall and no access to safe drinking water (El-Keblawy \& Al-Shamsi, 2008).

Ruminants can survive for up to three consecutive days without consuming water, but with some decrease in their productive performance (Aganga et al., 1990). This is possible only if the ruminant and the rumen microorganisms are adapted to these changes in osmolarity of the body's fluids. As a result, the microorganisms in the rumen tend to be tolerant to high concentrations of chloride $\left(\mathrm{Cl}^{-}\right)$, magnesium $\left(\mathrm{Mg}^{2+}\right)$, calcium $\left(\mathrm{Ca}^{2+}\right)$, and sodium $\left(\mathrm{Na}^{+}\right)$ions in the rumen fluid.

Animal tolerance to salinity varies according to species, age, water requirements, and physiological conditions (NRC, 2007). Among ruminant animals, goats and sheep are more tolerant of saline water than cattle, in part because of their size (Albuquerque, 2012). High levels of salinity may inhibit water consumption and consequently food intake (Balsalobre et al., 2007). The consumption of brackish water can reduce animal productivity as a consequence of the effects on rumen microorganisms and result in economic losses for the producer. 
Brackish waters are characterized by high levels of $\mathrm{Cl}^{-}, \mathrm{Mg}^{2+}, \mathrm{Ca}^{2+}$ and $\mathrm{Na}^{+}$(Manera et al., 2016), and may be important sources of minerals for ruminants. Nevertheless, high levels of these minerals may affect the activity of rumen microorganisms negatively. Studies by Yousfi et al. (2017) observed that incremental additions of salt to the water did not alter the number of protozoa in sheep rumen. However, little is known about this effect in goats. Thus, information from the literature is incomplete, but is especially important in regions where people and animals compete for scarce drinking water. Therefore, the present study was designed to evaluate the effects of differing concentrations of $\mathrm{NaCl}, \mathrm{MgCl}_{2}$ and $\mathrm{CaCl}_{2}$ on the growth and fermentation of cellulolytic, glycolytic, and amylolytic microorganisms in rumen fluid collected from goats.

\section{Material and Methods}

The study was undertaken in accordance with the technical norms of biosafety and ethics, and on approval by the Ethics Committee in the Use of Animals of the Centre for Biotechnology (CBiotec) of the Federal University of Paraíba (UFPB) (document 022/2012). In vitro trials were carried out at the Laboratory of Forage Crops at the Department of Animal Science of UFPB, Areia, Paraíba, Brazil, between October 2013 and August 2014. The experiment involved three rumen-cannulated goats that were housed at the Unit for Research with Large Ruminants, which is maintained by the Department of Animal Science of UFPB.

The individual effects of three salts $\left(\mathrm{NaCl}, \mathrm{MgCl}_{2}\right.$, and $\left.\mathrm{CaCl}_{2}\right)$ were evaluated at differing concentrations in the culture medium. These six levels of the salts were evaluated, namely 0, 100, 200, 400, 800 , and $1600 \mathrm{mg} / \mathrm{dL}$. The experiments were conducted as a completely randomized design in a $6 \times 3$ factorial arrangement consisting of six levels of salt and three substrates (starch, cellulose, and glucose), with three replicates.

Rumen fluid was collected from the goats four hours after feeding to obtain inoculant that contained an active microbial population. At the laboratory, the fluid was saturated with carbon dioxide, and left to stand at $39{ }^{\circ} \mathrm{C}$. After the formation of liquid interfaces, the intermediate fluid was collected and centrifuged at $500 \times \mathrm{g}$ for 10 minutes (Oliveira et al., 2012). The supernatant was discarded. The residue (pellet) from centrifugation containing predominant bacteria in the rumen fluid was re-suspended in McDougall's buffer $\left(9.80 \mathrm{~g} \mathrm{NaHCO}_{3}\right.$; $4.65 \mathrm{~g} \mathrm{Na}_{2} \mathrm{HPO}_{4}{ }^{*} 2 \mathrm{H}_{2} \mathrm{O} ; 0.57 \mathrm{~g} \mathrm{KCl} ; 0.12 \mathrm{~g} \mathrm{MgSO}_{4}{ }^{*} 7 \mathrm{H}_{2} \mathrm{O}$; and $0.04 \mathrm{~g} \mathrm{CaCl}_{2}$ dissolved in $1000 \mathrm{~mL}$ of distilled water).

Incubation bottles were filled with $16 \mathrm{~mL}$ McDougall's buffer and $4 \mathrm{~mL}$ inoculant, $150 \mathrm{mg}$ substrate, and the requisite amount of a salt. Starch, cellulose, and glucose were used as substrates for the rumen microorganisms. Each bottle was saturated with carbon dioxide to maintain a pH between 6.00 and 7.00, closed with a special lid, and sealed with tape to prevent contact with the incubation medium. They were then incubated at $39{ }^{\circ} \mathrm{C}$ in an agitated $(35 \mathrm{rpm})$ water bath for 48 hours. A sample was obtained from each bottle at $0,6,12,24$ and 48 hours of incubation with a syringe that was inserted through the lid of the bottle to prevent oxygen from entering. The $\mathrm{pH}$ was measured with a digital potentiometer at incubation times of 0 and 48 hours. At each sampling time, a $2.0 \mathrm{~mL}$ sample was collected from the culture medium of each experimental unit and placed in an Eppendor ${ }^{\Theta}$ tube, which was then centrifuged in a microcentrifuge at $1,200 \times \mathrm{g}$ for $10 \mathrm{~min}$. The supernatant was frozen for further analyses of $\mathrm{NH}_{3}-\mathrm{N}$ and volatile fatty acids (VFA). The pellet, which contained the predominant microorganisms from the rumen fluid, was re-suspended in $0.9 \%$ saline solution, homogenized, and re-centrifuged at $1200 \times \mathrm{g}$ for $10 \mathrm{~min}$ and the supernatant was discarded. The pellet formed during the last centrifugation was re-suspended in $0.9 \%$ saline solution and frozen at $-10^{\circ} \mathrm{C}$ for later analysis of microbial protein.

For the analysis of VFA, $500 \mu \mathrm{L}$ supernatant was collected, $500 \mu \mathrm{L} 25 \%$ metaphosphoric acid was added, and the mixture was poured into Eppendorf tubes. The material was analysed in a high-performance liquid chromatograph (SPD-10A VP, Shimadzu Corp., Kyoto, Japan), which was coupled to an ultraviolet detector, at a wavelength of $210 \mathrm{~nm}$. Ammonia nitrogen concentration was determined by a colorimetric method, and protein concentration was quantified by Bradford's (1976) method. Electric conductivity (dS/m) was measured at zero time and at 48 hours of incubation, using a conductivity meter.

The experiment was conducted as a completely randomized $6 \times 3$ factorial arrangement of treatments with three replications. The results from each substrate were analysed separately. Thus, the linear model:

$$
Y_{i j}=\mu+\alpha_{i}+\varepsilon_{i j}
$$

where: $Y_{\mathrm{ij}}=$ dependent variable;

$\mu=$ overall mean;

$\alpha i=$ fixed effect of ith levels of a salt; and

$\varepsilon i j=$ error associated with observation Yij was used to analyse the data.

A similar regression model was used in which the levels of salt were regarded as a continuous variate with the linear and quadratic effects being tested. All statistical analyses were performed using the GLM 
procedure of the SAS ${ }^{\circledR}$ System for Windows 9.4 (SAS Institute Inc., Cary, North Carolina, USA). Effects were declared significant at $P=0.05$.

\section{Results and Discussion}

The linear effects $(P<0.05)$ of $\mathrm{NaCl}, \mathrm{MgCl}_{2}$ and $\mathrm{CaCl}_{2}$ showed that conductivity of the medium increased with the level of each salt (Table 1). Thus, media with a higher concentration of salt invariably had greater conductivity. This was expected (Santos, 2012). Cellulose-based media had higher electrical conductivity with $1600 \mathrm{mg} / \mathrm{dL}$ of each salt compared with other substrates. Media that contained starch had the lowest values of electrical conductivity with $1600 \mathrm{mg} / \mathrm{dL}$ of $\mathrm{MgCl}_{2}$ and $\mathrm{CaCl}_{2}$ in the media.

Table 1 Values of electrical conductivity $(\mathrm{dS} / \mathrm{m})$ of the in vitro culture media with different concentrations of sodium chloride, magnesium chloride and calcium chloride

\begin{tabular}{|c|c|c|c|c|c|c|c|c|c|c|}
\hline \multicolumn{2}{|c|}{ Media } & \multicolumn{6}{|c|}{ Levels of salt (mg/dL) } & \multirow[b]{2}{*}{ SE } & \multicolumn{2}{|c|}{ Significance } \\
\hline Salt & Substrate & 0 & 100 & 200 & 400 & 800 & 1600 & & Linear & Quadratic \\
\hline \multirow[t]{3}{*}{$\mathrm{NaCl}$} & Starch & 11.06 & 11.80 & 13.14 & 14.71 & 22.47 & 34.48 & 0.29 & $<.0001$ & $<.0001$ \\
\hline & Cellulose & 10.42 & 11.34 & 12.78 & 14.39 & 22.85 & 35.68 & 0.29 & $<.0001$ & $<.0001$ \\
\hline & Glucose & 11.28 & 11.87 & 13.19 & 14.68 & 22.75 & 34.26 & 0.29 & $<.0001$ & $<.0001$ \\
\hline \multirow[t]{3}{*}{$\mathrm{MgCl}_{2}$} & Starch & 15.68 & 15.33 & 15.56 & 16.04 & 17.22 & 20.52 & 0.56 & $<.0001$ & 0.0191 \\
\hline & Cellulose & 19.58 & 18.85 & 19.02 & 19.12 & 21.55 & 25.55 & 0.56 & $<.0001$ & 0.0006 \\
\hline & Glucose & 15.80 & 16.11 & 16.07 & 16.54 & 17.18 & 22.67 & 0.56 & $<.0001$ & $<.0001$ \\
\hline \multirow[t]{3}{*}{$\mathrm{CaCl}_{2}$} & Starch & 16.08 & 15.71 & 16.20 & 16.62 & 17.56 & 23.72 & 0.47 & $<.0001$ & $<.0001$ \\
\hline & Cellulose & 19.56 & 18.76 & 19.48 & 21.41 & 23.18 & 28.03 & 0.47 & $<.0001$ & 0.3159 \\
\hline & Glucose & 16.38 & 16.50 & 16.96 & 17.00 & 18.06 & 25.35 & 0.47 & $<.0001$ & $<.0001$ \\
\hline
\end{tabular}

$\mathrm{NaCl}$ : sodium chloride, $\mathrm{MgCl}_{2}$ : magnesium chloride, $\mathrm{CaCl}_{2}$ : calcium chloride

Sodium chloride did not affect the growth of amylolytic microorganisms (Table 2). The $\mathrm{MgCl}_{2}$ and $\mathrm{CaCl}_{2}$ concentrations had an increasing linear effect $(P<0.05)$ on the microbial protein concentration when the substrate was starch. There was no effect of $\mathrm{NaCl}$ or $\mathrm{MgCl}_{2}$ concentration on microbial protein in the medium containing cellulose. The quadratic effect of $\mathrm{CaCl}_{2}$ on the growth of cellulolytic microorganisms was significant ,with an estimated peak at a concentration of $751 \mathrm{mg} / \mathrm{dL}$ of this salt. There were no effects of $\mathrm{NaCl}$ and $\mathrm{MgCl}_{2}$ on the concentration of microbial protein in the medium with glucose. The quadratic effect of $\mathrm{CaCl}_{2}$ concentration on microbial protein production was significant in the glucose-based medium with an estimated peak at a $\mathrm{CaCl}_{2}$ concentration of $550 \mathrm{mg} / \mathrm{dL}$. However, this result might be entirely because of the markedly depressed quantity of microbial protein in the medium that contained $800 \mathrm{mg} / \mathrm{dL}$ of the salt.

Ingestion of water with up to $100 \mathrm{mg} / \mathrm{dl}$ of $\mathrm{NaCl}$ and $\mathrm{MgCl}_{2}$ probably did not inhibit the growth of rumen microbes, whether the diet was rich in fibre or in non-fibre carbohydrates. However, high concentrations of $\mathrm{CaCl}_{2}$ did inhibit microbial growth. Costa et al. (2019) observed that the growth of microorganisms in the starch-based medium was not affected by salt concentrations up to $1600 \mathrm{mg} / \mathrm{dL}$. This finding was interpreted to show that amylolytic microorganisms are more tolerant to high levels of salinity.

The growth rate of ruminal microorganisms may be limited by several factors, including salt concentrations in the media. Protein synthesis appears to be the most relevant factor. Different substrates may require different metabolic pathways (enzyme, transport protein, etc.) and a substantial quantity of amino acids can be directed to this metabolic activity (Argolô, 2007).

$\mathrm{NaCl}$ and $\mathrm{MgCl}_{2}$ levels did not affect $\mathrm{NH}_{3}-\mathrm{N}$ concentrations in the medium containing starch (Table 3). This demonstrates that in an environment that is favourable to the growth of amylolytic bacteria, concentrations of $\mathrm{NaCl}$ up to $1600 \mathrm{mg} / \mathrm{dL}$ do not impede nitrogen metabolism. However, in a starch-based medium, escalating levels of $\mathrm{CaCl}_{2}(P<0.05)$ increased the production of $\mathrm{NH}_{3}-\mathrm{N}$ linearly over 48 hours of incubation. This increasing accumulation of $\mathrm{NH}_{3}-\mathrm{N}$ in the medium containing starch was a consequence of the observed lower microbial protein synthesis, because of the inhibition of the microorganisms. The concentration of $\mathrm{NH}_{3}-\mathrm{N}$ is thus a consequence of the balance between the production and use of microbial protein by microorganisms, according to the available energy. Likewise, the lower concentration of $\mathrm{NH}_{3}-\mathrm{N}$ in 
the medium with glucose was because of its use for growth by various bacterial species. An increasing linear effect of $\mathrm{NaCl}$ and a decreasing linear effect of $\mathrm{MgCl}_{2}$ concentration on $\mathrm{NH}_{3}-\mathrm{N}$ were also observed. In the cellulose-based media, in which $1600 \mathrm{mg} / \mathrm{dL}$ of $\mathrm{MgCl}_{2}$ produced the lowest level of NH3-N. The levels of $\mathrm{CaCl}_{2}$ did not affect the concentration of $\mathrm{NH}_{3}-\mathrm{N}$ that was produced in this medium. Likewise, there were no effects of $\mathrm{NaCl}$ and $\mathrm{MgCl}_{2}$ salts on $\mathrm{NH}_{3}-\mathrm{N}$ concentration in the medium containing glucose. However, there was a quadratic effect of $\mathrm{CaCl}_{2}$ on $\mathrm{NH}_{3}-\mathrm{N}$ concentration in the presence of glucose.

Table 2 Microbial protein produced $(\mathrm{mg} / \mathrm{dL})$ during 48 hours of in vitro incubation in media with various concentrations of sodium chloride, magnesium chloride and calcium chloride

\begin{tabular}{|c|c|c|c|c|c|c|c|c|c|c|}
\hline \multicolumn{2}{|c|}{ Media } & \multicolumn{6}{|c|}{ Levels of salt (mg/dL) } & \multirow{2}{*}{ SE } & \multicolumn{2}{|c|}{ Significance } \\
\hline Salt & Substrate & 0 & 100 & 200 & 400 & 800 & 1600 & & Linear & Quadratic \\
\hline \multirow[t]{3}{*}{$\mathrm{NaCl}$} & Starch & 1423.2 & 1372.1 & 1440.4 & 1423.2 & 1705.4 & 1493.8 & 228.8 & 0.339 & 0.212 \\
\hline & Cellulose & 1346.0 & 1804.3 & 1708.2 & 1549.3 & 1447.1 & 1310.4 & 228.8 & 0.064 & 0.553 \\
\hline & Glucose & 1383.8 & 1717.1 & 1687.1 & 1911.0 & 1666.6 & 1478.8 & 228.8 & 0.527 & 0.035 \\
\hline \multirow{3}{*}{$\mathrm{MgCl}_{2}$} & Starch & 933.2 & 1042.0 & 1093.6 & 1075.4 & 1096.3 & 1130.5 & 122.3 & 0.037 & 0.379 \\
\hline & Cellulose & 1031.4 & 1048.8 & 1030.9 & 1008.8 & 1122.5 & 1144.8 & 122.3 & 0.124 & 0.382 \\
\hline & Glucose & 1267.4 & 1162.5 & 1133.6 & 1190.9 & 1203.9 & 1214.5 & 122.3 & 0.930 & 0.946 \\
\hline \multirow[t]{3}{*}{$\mathrm{CaCl}_{2}$} & Starch & 1416.2 & 1418.4 & 2098.4 & 1756.2 & 1825.1 & 951.8 & 263.3 & 0.008 & 0.004 \\
\hline & Cellulose & 1789.6 & 1658.4 & 1876.2 & 1327.3 & 1916.2 & 1169.6 & 263.3 & 0.175 & 0.039 \\
\hline & Glucose & 2020.7 & 1802.9 & 1896.2 & 1854.0 & 1111.8 & 2118.4 & 263.3 & 0.005 & 0.009 \\
\hline
\end{tabular}

$\mathrm{NaCl}$ : sodium chloride, $\mathrm{MgCl}_{2}$ : magnesium chloride, $\mathrm{CaCl}_{2}$ : calcium chloride

Table 3 Ammonia nitrogen produced $(\mathrm{mM})$ during 48 hours in vitro incubation in media with various concentrations of sodium chloride, magnesium chloride and calcium chloride

\begin{tabular}{|c|c|c|c|c|c|c|c|c|c|c|}
\hline \multicolumn{2}{|l|}{ Media } & \multicolumn{6}{|c|}{ Levels of salt $(\mathrm{mg} / \mathrm{dL})$} & \multirow{2}{*}{ SE } & \multicolumn{2}{|c|}{ Significance } \\
\hline Salt & Substrate & 0 & 100 & 200 & 400 & 800 & 1600 & & Linear & Quadratic \\
\hline \multirow[t]{3}{*}{$\mathrm{NaCl}$} & Starch & 10.87 & 11.84 & 10.68 & 11.65 & 11.73 & 12.42 & 3.45 & 0.5797 & 0.9906 \\
\hline & Cellulose & 9.54 & 10.85 & 9.05 & 8.97 & 11.12 & 15.71 & 3.45 & 0.0155 & 0.3206 \\
\hline & Glucose & 13.22 & 10.00 & 9.40 & 6.97 & 10.02 & 12.33 & 3.45 & 0.6092 & 0.0792 \\
\hline \multirow[t]{3}{*}{$\mathrm{MgCl}_{2}$} & Starch & 3.14 & 2.80 & 1.48 & 2.88 & 1.61 & 0.78 & 2.94 & 0.3212 & 0.9495 \\
\hline & Cellulose & 15.70 & 19.80 & 10.13 & 5.82 & 2.73 & 4.35 & 2.94 & $<.0001$ & $<.0001$ \\
\hline & Glucose & 6.17 & 1.98 & 1.88 & 1.96 & 1.34 & 1.16 & 2.94 & 0.1696 & 0.2449 \\
\hline \multirow[t]{3}{*}{$\mathrm{CaCl}_{2}$} & Starch & 2.61 & 4.63 & 4.04 & 4.06 & 10.80 & 7.29 & 2.16 & 0.0089 & 0.0277 \\
\hline & Cellulose & 1.97 & 4.15 & 29.57 & 7.81 & 6.51 & 10.74 & 2.16 & 0.8321 & 0.2326 \\
\hline & Glucose & 19.09 & 14.26 & 12.08 & 6.24 & 12.64 & 9.86 & 2.16 & 0.0073 & 0.0073 \\
\hline
\end{tabular}

$\mathrm{NaCl}$ : sodium chloride, $\mathrm{MgCl}_{2}$ : magnesium chloride, $\mathrm{CaCl}_{2}$ : calcium chloride

The ingestion of saline water that contains high levels of $\mathrm{CaCl}_{2}$, together with diets composed of soluble carbohydrates, could affect the production of $\mathrm{NH}_{3}-\mathrm{N}$. On the other hand, diets containing fibrous carbohydrates may interfere with $\mathrm{NH}_{3}-\mathrm{N}$ production when animals consume water with high levels of $\mathrm{MgCl}_{2}$. Thus, for fattening sheep that received high-concentrate diets, Mehrez et al. (1977) suggested $23 \mathrm{mg} / 100$ $\mathrm{mL}$ ruminal fluid as the minimum concentration of $\mathrm{NH}_{3}-\mathrm{N}$ to obtain a maximum microbial growth rate. Valtorta et al. (2008) found no effect of salinity on ruminal bacteria, protozoa, $\mathrm{pH}, \mathrm{NH}_{3}-\mathrm{N}$, and VFA in dairy cows, illustrating the rumen buffering capacity, probably because of effects of the substrate. 
The effect of $\mathrm{NaCl}$ concentration on acetate production by rumen microbes in the medium containing starch was curvilinear (Table 4) with a maximum at $210 \mathrm{mg} / \mathrm{dL}$ of $\mathrm{NaCl}$. Similarly, Alves et al. (2017) observed a linear reduction in digestibility of neutral detergent fibre when cattle consumed water with a high content of $\mathrm{NaCl}$. The levels of $\mathrm{MgCl}_{2}$ and $\mathrm{CaCl}_{2}$ in the media also produced linear decreases in the concentration of acetate. There was no observed effect of $\mathrm{NaCl}$ on acetate production when the substrate was cellulose. However, there was a quadratic effect of $\mathrm{MgCl}_{2}$ concentration on acetate production with the cellulose-based medium. Estimated microbial production of acetate was minimized with $645 \mathrm{mg} / \mathrm{dL} \mathrm{of} \mathrm{MgCl}_{2}$ in the cellulose-based medium. The effect of $\mathrm{CaCl}_{2}$ levels in the medium containing cellulose on the acetate production was linear and decreasing with increasing levels of $\mathrm{CaCl}_{2}$. In the media containing $\mathrm{NaCl}$ and $\mathrm{MgCl}_{2}$ and the starch substrate the microbes produced more acetate than in media containing cellulose and glucose.

Table 4 Acetate produced $(\mathrm{mM})$ during 48 hours in vitro incubation in media with various concentrations of sodium chloride, magnesium chloride and calcium chloride

\begin{tabular}{|c|c|c|c|c|c|c|c|c|c|c|}
\hline \multicolumn{2}{|l|}{ Media } & \multicolumn{6}{|c|}{ Levels of salt (mg/dL) } & \multirow{2}{*}{ SE } & \multicolumn{2}{|c|}{ Significance } \\
\hline Salt & Substrate & 0 & 100 & 200 & 400 & 800 & 1600 & & Linear & Quadratic \\
\hline \multirow[t]{3}{*}{$\mathrm{NaCl}$} & Starch & 33.43 & 41.88 & 41.27 & 40.84 & 41.96 & 25.76 & 4.98 & 0.0022 & 0.0011 \\
\hline & Cellulose & 16.21 & 12.84 & 10.95 & 10.81 & 10.78 & 14.38 & 4.98 & 0.9635 & 0.1386 \\
\hline & Glucose & 28.89 & 20.73 & 19.79 & 30.75 & 28.62 & 26.59 & 4.98 & 0.3723 & 0.3341 \\
\hline \multirow[t]{3}{*}{$\mathrm{MgCl}_{2}$} & Starch & 33.41 & 33.58 & 31.20 & 34.34 & 34.04 & 23.60 & 3.54 & 0.0009 & 0.0260 \\
\hline & Cellulose & 21.94 & 20.37 & 17.13 & 17.30 & 15.49 & 20.33 & 3.54 & 0.7567 & 0.0159 \\
\hline & Glucose & 24.75 & 26.34 & 27.91 & 26.68 & 23.96 & 23.25 & 3.54 & 0.1832 & 0.7671 \\
\hline \multirow[t]{3}{*}{$\mathrm{CaCl}_{2}$} & Starch & 25.35 & 24.37 & 24.80 & 26.43 & 23.56 & 17.97 & 4.04 & 0.0148 & 0.2977 \\
\hline & Cellulose & 17.39 & 18.27 & 16.90 & 16.39 & 18.10 & 26.45 & 4.04 & 0.0032 & 0.1061 \\
\hline & Glucose & 33.61 & 36.55 & 32.96 & 27.72 & 23.41 & 25.77 & 4.04 & 0.0007 & 0.0107 \\
\hline
\end{tabular}

$\mathrm{NaCl}$ : sodium chloride, $\mathrm{MgCl}_{2}$ : magnesium chloride, $\mathrm{CaCl}_{2}$ : calcium chloride

In the medium containing starch, increased $\mathrm{NaCl}, \mathrm{MgCl}_{2}$, and $\mathrm{CaCl}_{2}$ concentrations decreased microbial production of propionate linearly (Table 5). Thus, these salts inhibit the use of propionate pathways by ruminal starch microorganisms. There was a quadratic effect of $\mathrm{CaCl}_{2}$ levels in the medium containing starch, which affected the concentration of propionate. It was estimated that the highest propionate level was produced with $720 \mathrm{mg} / \mathrm{dL}$ of $\mathrm{CaCl}_{2}(23.01 \mathrm{mM})$ in the media. Further, there were no effects of $\mathrm{NaCl}$ concentration on propionate production in the media containing cellulose and glucose as substrate. Similarly, the level of $\mathrm{CaCl}_{2}$ did not affect propionate production when the medium contained glucose. However, there was an increasing linear behaviour of this salt on the propionate production in the cellulose-based medium, which invariably yielded less propionate. Microorganisms that use beta-glucose as an energy source generally use the acetate pathway instead of propionate acetate for nicotinamide adenine dinucleotide (NAD) re-oxidation, under suitable $\mathrm{pH}$ conditions (Moss et al., 2000). Thus, a lower propionate concentration was expected when the medium contained cellulose compared with media that contained starch and glucose.

Butyrate production decreased linearly as a function of the concentration of $\mathrm{NaCl}, \mathrm{MgCl}_{2}$, and $\mathrm{CaCl}_{2}$ in the medium containing starch (Table 6). However, there was no effect of the level of $\mathrm{NaCl}, \mathrm{MgCl}_{2}$, and $\mathrm{CaCl}_{2}$ on microbial production of butyrate in the cellulose-based medium. This demonstrates that cellulose fermenting microorganisms and butyrate producers are not sensitive to salt concentrations up to 1600 $\mathrm{mg} / \mathrm{dL}$. Rumen microorganisms that use the butyrate pathway to re-oxidize nicotinamide-adenine dinucleotide (reduced) generally do not have enzymes capable of re-oxidizing the reduced form of NAD by other pathways (Moss et al., 2000). Thus, the decreasing linear effects $(P<0.05)$ of $\mathrm{NaCl}, \mathrm{MgCl}_{2}$, and $\mathrm{CaCl}_{2}$ concentrations in the starch and the effect of $\mathrm{MgCl}_{2}$ in the medium containing glucose are because of the inhibition of amylolytic and glycolytic microorganisms that produce butyrate. 
Table 5 Propionate produced $(\mathrm{mM})$ during 48 hours in vitro incubation in media with various concentrations of sodium chloride, magnesium chloride and calcium chloride

\begin{tabular}{|c|c|c|c|c|c|c|c|c|c|c|}
\hline \multicolumn{4}{|l|}{ Media } & \multicolumn{4}{|c|}{ Levels of salt (mg/dL) } & \multirow{2}{*}{ SE } & \multicolumn{2}{|c|}{ Significance } \\
\hline Salt & Substrate & 0 & 100 & 200 & 400 & 800 & 1600 & & Linear & Quadratic \\
\hline \multirow[t]{3}{*}{$\mathrm{NaCl}$} & Starch & 26.43 & 26.80 & 26.03 & 26.23 & 27.99 & 16.94 & 3.61 & 0.0012 & 0.0267 \\
\hline & Cellulose & 9.52 & 7.99 & 6.51 & 6.32 & 7.45 & 8.86 & 3.61 & 0.8160 & 0.3230 \\
\hline & Glucose & 19.98 & 13.25 & 13.33 & 24.33 & 18.06 & 16.64 & 3.61 & 0.9317 & 0.1756 \\
\hline \multirow[t]{3}{*}{$\mathrm{MgCl}_{2}$} & Starch & 22.94 & 21.94 & 17.51 & 23.54 & 20.90 & 16.10 & 2.35 & 0.0025 & 0.2028 \\
\hline & Cellulose & 12.61 & 10.60 & 10.34 & 11.42 & 11.66 & 12.69 & 2.35 & 0.4126 & 0.5695 \\
\hline & Glucose & 18.54 & 17.76 & 17.13 & 16.25 & 14.72 & 14.59 & 2.35 & 0.0236 & 0.2356 \\
\hline \multirow[t]{3}{*}{$\mathrm{CaCl}_{2}$} & Starch & 20.80 & 17.90 & 18.30 & 21.39 & 23.01 & 11.79 & 3.23 & 0.0067 & 0.0031 \\
\hline & Cellulose & 12.72 & 13.00 & 11.95 & 12.49 & 12.50 & 17.60 & 3.23 & 0.0394 & 0.2191 \\
\hline & Glucose & 23.14 & 23.85 & 19.36 & 22.13 & 17.87 & 20.51 & 3.23 & 0.1944 & 0.1150 \\
\hline
\end{tabular}

$\mathrm{NaCl}$ : sodium chloride, $\mathrm{MgCl}_{2}$ : magnesium chloride, $\mathrm{CaCl}_{2}$ : calcium chloride

Table 6 Butyrate produced $(\mathrm{mM})$ during 48 hours in vitro incubation in media with various concentrations of sodium chloride, magnesium chloride and calcium chloride

\begin{tabular}{|c|c|c|c|c|c|c|c|c|c|c|}
\hline \multicolumn{4}{|l|}{ Media } & \multicolumn{4}{|c|}{ Levels of salt (mg/dL) } & \multirow{2}{*}{ SE } & \multicolumn{2}{|c|}{ Significance } \\
\hline Salt & Substrate & 0 & 100 & 200 & 400 & 800 & 1600 & & Linear & Quadratic \\
\hline \multirow[t]{3}{*}{$\mathrm{NaCl}$} & Starch & 14.09 & 13.91 & 14.08 & 13.35 & 14.64 & 8.80 & 2.04 & 0.0016 & 0.0573 \\
\hline & Cellulose & 4.81 & 4.66 & 6.55 & 5.15 & 4.27 & 5.01 & 2.04 & 0.7699 & 0.8478 \\
\hline & Glucose & 10.61 & 7.37 & 7.06 & 12.87 & 9.90 & 9.76 & 2.04 & 0.5007 & 0.2912 \\
\hline \multirow[t]{3}{*}{$\mathrm{MgCl}_{2}$} & Starch & 12.90 & 13.91 & 10.08 & 11.92 & 10.87 & 8.76 & 1.38 & 0.0002 & 0.7392 \\
\hline & Cellulose & 6.31 & 5.95 & 6.28 & 5.96 & 6.48 & 7.13 & 1.38 & 0.2978 & 0.7131 \\
\hline & Glucose & 10.23 & 10.07 & 8.30 & 8.00 & 8.31 & 7.12 & 1.38 & 0.0089 & 0.2978 \\
\hline \multirow[t]{3}{*}{$\mathrm{CaCl}_{2}$} & Starch & 11.60 & 10.23 & 8.72 & 11.36 & 11.42 & 6.29 & 1.67 & 0.0022 & 0.0292 \\
\hline & Cellulose & 6.41 & 7.75 & 7.05 & 7.40 & 6.71 & 9.40 & 1.67 & 0.0645 & 0.3438 \\
\hline & Glucose & 11.51 & 12.79 & 10.09 & 11.6 & 9.81 & 11.53 & 1.67 & 0.6693 & 0.1697 \\
\hline
\end{tabular}

$\mathrm{NaCl}$ : sodium chloride, $\mathrm{MgCl}_{2}$ : magnesium chloride, $\mathrm{CaCl}_{2}$ : calcium chloride

There was a quadratic effect of $\mathrm{NaCl}$ levels on $\mathrm{pH}$ in the medium containing starch (Table 7). The estimated maximum $\mathrm{pH}$ was predicted to be 7.03 at a $\mathrm{NaCl}$ concentration of $120 \mathrm{mg} / \mathrm{dL}$. In the medium containing cellulose, $\mathrm{pH}$ increased linearly with the concentration of $\mathrm{NaCl}$. The microorganisms that digest cellulose prefer a pH value of 6.7. Deviations above or below this $\mathrm{pH}$ might be inhibitory. Thus, increasing levels of $\mathrm{NaCl}$ can result in low cellulolytic bacteria activity (Church, 1974). There was no effect of $\mathrm{MgCl}_{2}$ levels on $\mathrm{pH}$ in any of the three substrates. However, there was a decreasing linear effect of $\mathrm{CaCl}_{2}$ on the $\mathrm{pH}$ in the media containing starch, cellulose, and glucose, with the lowest $\mathrm{pH}$ values being 6.40,6.97, and 6.00, respectively.

Ruminal microorganisms that grew in the media containing glucose and often starch were sensitive to increasing levels of $\mathrm{NaCl}, \mathrm{MgCl}_{2}$, and $\mathrm{CaCl}_{2}$. However, microorganisms in the medium obtaining cellulose were less sensitive to increasing concentrations of these salts, even though the $\mathrm{pH}$ increased with the concentrations of the salts. Thus, under the conditions imposed in this study, there was little variation in the microbial protein production and in the fermentation products when the microorganisms were provided with cellulose as a substrate. In general, the effect of $\mathrm{NaCl}$ concentration in the media was smaller than those of $\mathrm{MgCl}_{2}$ and $\mathrm{CaCl}_{2}$, demonstrating that rumen microorganisms are less sensitive to $\mathrm{NaCl}$. In the medium containing starch as substrate, high levels of $\mathrm{MgCl}_{2}$ inhibited the growth of the rumen microorganisms. In 
contrast, when cellulose was used as a substrate, the effect of $\mathrm{MgCl}_{2}$ on the rumen microorganisms was smaller, demonstrating that cellulolytic and glycolytic microorganisms were less sensitive to this salt. With all three substrates, the effects of $\mathrm{CaCl}_{2}$ on the rumen microorganisms were comparatively small, demonstrating that the amylolytic, cellulolytic, and glycolytic microorganisms were less sensitive to $\mathrm{CaCl}_{2}$ than to other salts. In the review by Umar et al. (2014), the quality and consumption of the drinking water was observed to decrease as excess solids were added, which resulted in reduced performance.

Table 7 Mean pH values after 48 hours of in vitro incubation in media with various concentrations of sodium chloride, magnesium chloride and calcium chloride

\begin{tabular}{|c|c|c|c|c|c|c|c|c|c|c|}
\hline \multicolumn{2}{|l|}{ Media } & \multicolumn{6}{|c|}{ Levels of salt (mg/dL) } & \multirow{2}{*}{ SE } & \multicolumn{2}{|c|}{ Significance } \\
\hline Salt & Substrate & 0 & 100 & 200 & 400 & 800 & 1600 & & Linear & Quadratic \\
\hline \multirow[t]{3}{*}{$\mathrm{NaCl}$} & Starch & 6.83 & 7.03 & 6.56 & 6.50 & 6.56 & 6.70 & 0.17 & 0.2022 & 0.0072 \\
\hline & Cellulose & 6.90 & 7.00 & 6.83 & 6.83 & 7.30 & 7.46 & 0.17 & $<.0001$ & 0.8613 \\
\hline & Glucose & 6.53 & 6.73 & 6.56 & 6.56 & 6.63 & 6.56 & 0.17 & 0.8113 & 0.7976 \\
\hline \multirow[t]{3}{*}{$\mathrm{MgCl}_{2}$} & Starch & 6.66 & 7.46 & 6.93 & 6.63 & 6.83 & 6.86 & 0.34 & 0.5804 & 0.5052 \\
\hline & Cellulose & 7.15 & 7.27 & 7.10 & 7.00 & 6.99 & 6.91 & 0.34 & 0.2454 & 0.6746 \\
\hline & Glucose & 7.14 & 6.94 & 6.78 & 6.56 & 6.96 & 6.66 & 0.34 & 0.2695 & 0.5978 \\
\hline \multirow[t]{3}{*}{$\mathrm{CaCl}_{2}$} & Starch & 6.98 & 7.00 & 6.97 & 6.91 & 6.72 & 6.40 & 0.063 & $<.0001$ & 0.3174 \\
\hline & Cellulose & 7.15 & 7.14 & 7.02 & 7.11 & 7.14 & 6.97 & 0.063 & 0.0043 & 0.1564 \\
\hline & Glucose & 6.98 & 6.95 & 6.87 & 6.74 & 6.55 & 6.00 & 0.063 & $<.0001$ & 0.5793 \\
\hline
\end{tabular}

$\mathrm{NaCl}$ : sodium chloride, $\mathrm{MgCl}_{2}$ : magnesium chloride, $\mathrm{CaCl}_{2}$ : calcium chloride

Saline water can affect microbial growth in the rumen negatively. The presence of solutes reduces the ability to dissolve additional solutes, which can influence plasma osmolarity. The solutes inhibit the movement of water through cells, causing reduced microbial activity (Al-Khalasi et al., 2010).

\section{Conclusions}

Rumen microbes from goats, which fermented in starch, cellulose, and glucose, tolerated $\mathrm{NaCl}$ and $\mathrm{CaCl}_{2}$ concentrations up to $1600 \mathrm{mg} / \mathrm{dL}$ in in vitro media. Neither cellulose or glucose were sensitive to $\mathrm{MgCl}_{2}$, tolerating concentrations of up to $1600 \mathrm{mg} / \mathrm{dL}$. However, bacteria that fermented in starch were less tolerant of $\mathrm{MgCl}_{2}$ concentrations above $800 \mathrm{mg} / \mathrm{dL}$. Thus, brackish water could be used by goats in semi-arid regions, but its use should be managed carefully so that it does not have a negative impact on rumen microbial populations.

\section{Acknowledgements}

The authors wish to thank FAPEMA (Maranhão State Research Foundation) for its financial support

\section{Authors' Contributions}

The idea for the study was conceived by EMS, who secured the funding and supervised GGLA, JSO, EMS and AMZ. ECBC was recruited as the student to work on the project and received her MSc cum laude. ECBC and GAP performed the experiment. AFP and FNSS were responsible for statistical analysis and structuring the manuscript formatting. EMS was the supervisor at the university and gave guidance on the study. All co-authors participated in management and discussion of the results, statistical analysis and writing, and corrected the manuscript. All authors read and approved the final manuscript.

\section{Conflict of Interest Declaration}

The authors declare there are no conflicts of interest

\section{References}

Albuquerque, I.R.R., 2012. Níveis de salinidade da água de beber para ovinos mestiços Santa Inês. Universidade Federal da Paraiba; Areia - PB. 
Aganga, A.A., Umunna, N.N., Oyedipe, E.O., Okoh, P.N. \& Aduku, A.O., 1990. Response to water deprivation by Yankasa ewes under different physiological states. Small Ruminant Res. 3(2), 109-115. https://doi.org/10.1016/0921-4488(90)90086-L

Al-Khalasi, S.S., Mahgoub, O, Kadim, I.T., Al-Marzooqi, W. \& Al-Rawahi, S.A., 2010. Salt tolerant fodder for Omani sheep (effects of salt-tolerant sorghum on performance, carcass, meat quality and health of Omani sheep). In: A. Mushtaque, S.A. Al-Rawahi \& N. Hussain, (eds). Monograph on management of salt-affected soils and water for sustainable agriculture. Sultan Qaboos University, Oman. pp. 67-81.

Araújo, G.G.L.D., Voltolini, T.V., Chizzotti, M.L., Turco, S.H.N. \& Carvalho, F.F.R.D., 2010. Water and small ruminant production. Braz. J. Anim. Sci. 39, 326-336.

Argôlo,L.S., 2007. Microbiota ruminal de cabras lactantes alimentadas com algaroba (prosopis juliflora (sw) d.c.): Análise funcional e molecular. Dissertação. Universidade Estadual Do Sudoeste Da Bahia - Uesb.

Balsalobre, M.A., Santos, P.M., Lima, N.R.C.B. Qualidade da agua: Salinidade. https://repositorio.ufpb.br/jspui/bitstream/123456789/15991/1/DZ255.pdf

Bradford, M.M., 1976. Rapid and sensitive method for quantitation of microgram quantities of protein utilising principle of protein dye binding. Analyt. Biochem. 72, 248-254.

Church, D.C., 1975. Digestive physiology and nutrition of ruminants. Volume I. O\&B Books, Inc. Corvallis, Oregon, USA. $340 \mathrm{pp}$.

Costa, E.C.B., Araújo, G.G.L., Oliveira, J.S., Santos, E.M., Henriques, L.T., Perazzo, A.F., Zanine, A.M., Pereira G.A. \& R.M.A. Pinho, R.M.A., 2019. Effect of salt concentrations on in vitro rumen fermentation of cellulose, starch, and protein. S. Afr. J. Anim. Sci. 49, 1139-1147.

El-Keblawy, A., Al-Shamsi, N., 2008. Salinity, temperature and light affect seed germination of Haloxylon salicornicum, a common perennial shrub of the Arabian deserts. Seed Science and Technology 36, 679-688.

Manera, D.B., Voltolini, T.V., Menezes, D.R. \& Araújo, G.L., 2016. Chemical composition of drilled wells water for ruminants. J. Agri. Sci. 8, 127-138.

Mehres, A. Z., Orskov, E.R., McDonald, I., 1977. Rates of rumen fermentation in relation to ammonia concentration. Br. J. Nutr. 38, 437-443.

Moss, A.R., Jouany, J.P., Newbold, J., 2000. Methane production by ruminants: Its contribution to global warming. INRA, EDP Sciences. Ann. Zootech. 49, 231-253.

National Research Council (NRC), 2007. Nutrient requirements of small ruminants: Sheep, goats, cervids, and New World camelids. Washington DC. 384 pp.

Santos, N.M.S.S., 2012. Salinidade da água na adaptabilidade de ovinos e respectivos dejetos no crescimento de plântulas de milho. Dissertação (Mestrado em Ciência Animal) Federal do Vale do São Francisco, Petrolina-PE

Oliveira, J.S., Queiroz, A.C.D., Mantovani, H.C., Bayão, G.F.V., Detmann, E., Santos, E.M. \& Silva, T.C.D., 2012. Evaluation of whey fermented by Enterococcus faecium in consortium with Veilonella parvula in ruminant feeding. Braz. J. Anim. Sci. 41, 172-180.

Umar, S., Munir, M.T., Azeem, T., Ali, S., Umar, W., Rehman, A. \& Shah, M.A., 2014. Effects of water quality on productivity and performance of livestock: A mini review. Vet. 2, 11-15

Valtorta, E.S., Gallardo, M.R., Sbodio, O.A., Revelli, G.R., Arakaki, C., Leva, E.P. \& Gaggiotti, M., 2008. Water salinity effects on performance and rumen parameters of lactating grazing Holstein cows. Int. J. Biometeorol. 52, 239247.

Yousfi, I., Ben Salem, H., Aouadi, D. \& Abidi, S., 2016. Effect of sodium chloride, sodium sulfate or sodium nitrite in drinking water on intake, digestion, growth rate, carcass traits and meat quality of Barbarine lamb. Small Ruminant Res. 143, 43-52. 